石油技術協会誌 第 83 巻 第 4 号 （平成 30 年 7 月） $257 \sim 266$ 頁 Journal of the Japanese Association for Petroleum Technology

Vol. 83, No. 4 (July, 2018) pp. 257 266

\begin{tabular}{cc}
\hline 報 & 告 \\
Technical Report
\end{tabular}

\title{
新潟地域における油・ガス田地層水の地球化学
}

\author{
加藤進 ${ }^{* \dagger}$
}

(Received February 26, 2018 ; accepted July 27, 2018)

\section{Geochemistry of formation waters from oil and gas fields in Niigata Prefecture, Japan}

Susumu Kato

\begin{abstract}
Chemical and isotopic compositions of formation waters from oil and gas fields in Niigata Prefecture, Japan, were examined to demonstrate their geochemical characteristics and stratigraphic change for each formation. They have the following geochemical characteristics.

1) The formation waters are mainly composed of $\mathrm{Na}^{+}$and $\mathrm{Cl}^{-}$ions.

2) Although they were originated from seawater (Kato and Kajiwara, 1986), their $\mathrm{SO}_{4}{ }^{2-}$ and $\mathrm{Mg}^{2+}$ contents have decreased rapidly and their $\mathrm{NH}_{4}{ }^{+}, \mathrm{I}^{-}$and $\mathrm{HCO}_{3}{ }^{-}$contents which are derived from organic matter have increased roughly in this order during burial diagenesis.

3) They have a relative narrow range of $\delta \mathrm{D}$ values between -15 and $-3 \%$ and large variations of $\delta^{18} \mathrm{O}$ values from -4.8 to $+1.6 \%$, similar to formation waters from oil and gas fields in Akita, Japan.

Their $\mathrm{Cl}^{-}$contents reach the maximum in the upper part of the Nishiyama Formation which is due to formation of authigenic minerals such as clay mineral and zeolite from volcanic glass, and decrease toward the underlying Shiiya and Teradomari formations. This decrease of $\mathrm{Cl}^{-}$content may be caused by release of waters from transformation of clay minerals and maturation of organic matter during burial of sediments.
\end{abstract}

Keywords : geochemistry, formation water, oil and gas field, Niigata, chemical composition, isotopic composition, seawater

\section{1.はじめに}

一般に, 油・ガス田では生産に伴って種々の水が産出す る。このうち地層水, 特に油田喴水は古くから研究され, その化学組成の特徽が良く知られており, 石油生成の副産 物とも考えられている（例えば, 高橋, $1932 \mathrm{a}, \mathrm{b})$ 。地層水 の化学組成は産出する水の同定（地層水かどうかの判定）, 物理検層解析, 二次回収法である水攻法の検討, 有用元素 (臭素，ヨウ素，リチウムなど）の回収などに利用にされ ている（加藤, 1990)。

新潟地域では石油探鉱はかなり進んだ段階にあり，稼行 された油・ガス田もすでに生産ピークを過ぎたり，廃山さ れたりしたものが多い。しかしながら，これらの油・ガス 田の地層水について地球化学的な視点から報告されたもの は須藤（1967）や加藤・梶原（1986）以降見当たらない。 これらの地層水の起源は堆積時の海水と考えられている が，その化学組成や水素・酸素同位体組成は海水とはかな

* (株地球科学総合研究所 JGI, Inc.

† Corresponding author : E-Mail : susumukato9@gmail.com
り異なっている(須藤, 1967; 加藤・梶原, 1986)。したがって, 地層水の化学組成や同位体組成は地層が受けてきた埋没続 成プロセスや地下での流体の移動や混合プロセスを反映し ていると考えられる。また，これらは大深度の温泉水（大 沢ほか，2010など）や“深部流体”（風早ほか，2014など） の起源を検討する上で必須のデータでもある。

本稿では新潟地域の油・ガス田（図 1）のうち, 石油資 源開発侏)が操業している（あるいはしていた）油・ガス田 から加藤・梶原（1986）以降に生産井から採取した地層水 について化学組成と同位体組成を報告する。化学組成につ いては，他の油・ガス田の地層水に関する文献（本島ほか, 1955 ; 相場, 1965 など）も用いて, 地層水の変質プロセ スの特徵とその要因を検討する。

\section{2. 地 質 概 説}

新潟地域坑井層序（工藤ほか, 2011）は年代層序であり, 「階」を用いるべきであるが, 本稿では従来の慣例にした がって「層」を用いる。各油・ガス田の坑井層序と対比マー カーを用いて, 本稿で取扱う油・ガス層の層準を認定した (図 2)。油・ガス層の岩質は砂岩あるいは凝灰質砂岩, 凝 


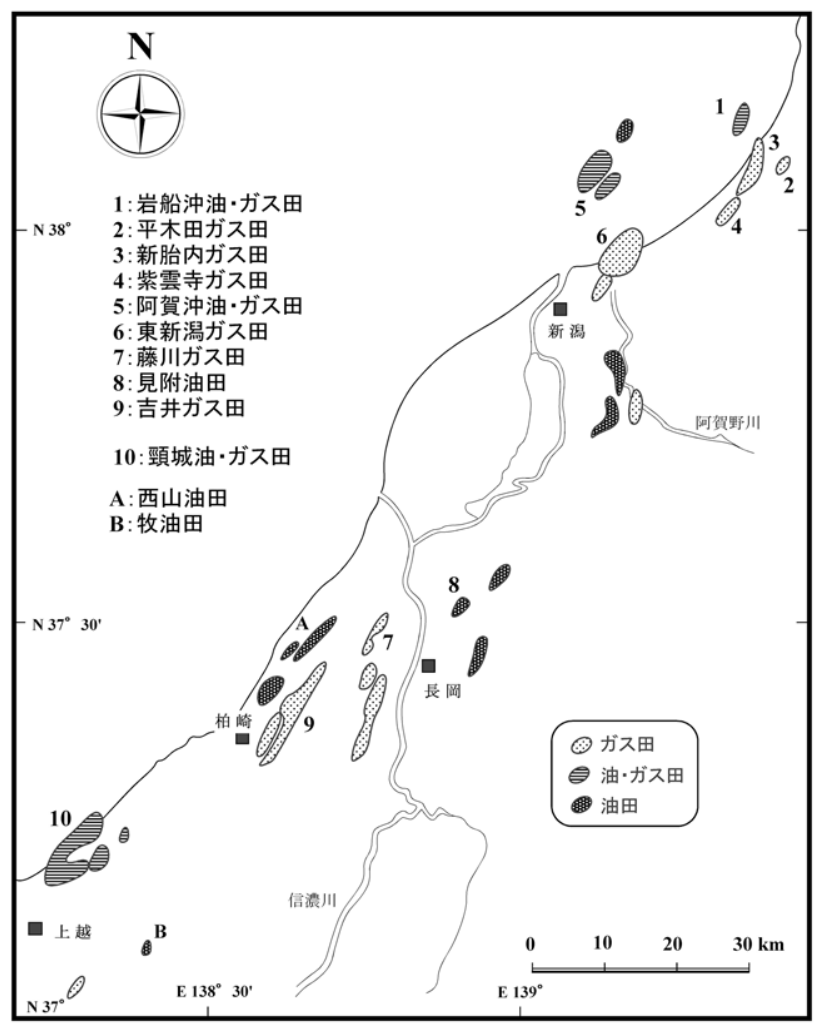

図 1 新潟地域の油・ガス田位置図
灰岩, 火山岩（流紋岩類）からなるが，七谷層が流紋岩や デイサイトの火山岩, 藤川ガス田の椎谷層が凝灰岩である のを除けば, 砂岩である。

油・ガス層の深度と温度の関係を図 3 に示す。油・ガ 又層の深度は約 $600 \mathrm{~m}$ から約 $3,000 \mathrm{~m}$ の範囲に分布してお り, 温度はおおよそ $40^{\circ} \mathrm{C} \sim 130^{\circ} \mathrm{C}$ である。地温勾配は $3^{\circ} \mathrm{C}$ $/ 100 \mathrm{~m} \sim 6{ }^{\circ} \mathrm{C} / 100 \mathrm{~m}$ であるが, 平木田ガス田を除けば大 部分が $4{ }^{\circ} \mathrm{C} / 100 \mathrm{~m}$ 前後である。

\section{3. 地層水の化学組成}

石油資源開発(株技術研究所で分析されたデータ（陽 イ オン: $\mathrm{Na}^{+}, \mathrm{K}^{+}, \mathrm{Ca}^{2+}, \mathrm{Mg}^{2+}, \mathrm{NH}_{4}{ }^{+}$, 陰 イ オン: $\mathrm{Cl}^{-}$, $\mathrm{SO}_{4}{ }^{2-}, \mathrm{HCO}_{3}{ }^{-}, \mathrm{I}^{-}, \mathrm{Br}^{-}$および水素・酸素同位体組成： $\delta \mathrm{D}$, $\left.\delta^{18} \mathrm{O}\right)$ によれば, 油・ガス層によって, あるいは同じ油・ ガス層でも坑井によって, さらには同一坑井でも採取時期 によって, 地層水の化学組成や同位体組成には若干のバラ ツキが認められる。それらのうち, 油・ガス田の代表的な 地層水の分析值を表 1 に示す。七谷層から灰爪層までの地 層は海成層であり, 初生的には孔隙は海水で充填されてい たと考えられる。また, 水素・酸素同位体組成などから地 層水は海水を起源としている（加藤・梶原，1986）ことか ら，海水の值も参考として示す。

地層水（表 1） は主に $\mathrm{Na}^{+}$と $\mathrm{Cl}^{-}$からなり, 海水と比較 すると, $\mathrm{SO}_{4}{ }^{2-} や \mathrm{Mg}^{2+}$ の濃度が著しく減少し, 有機物と密
地質年代 坑井層序

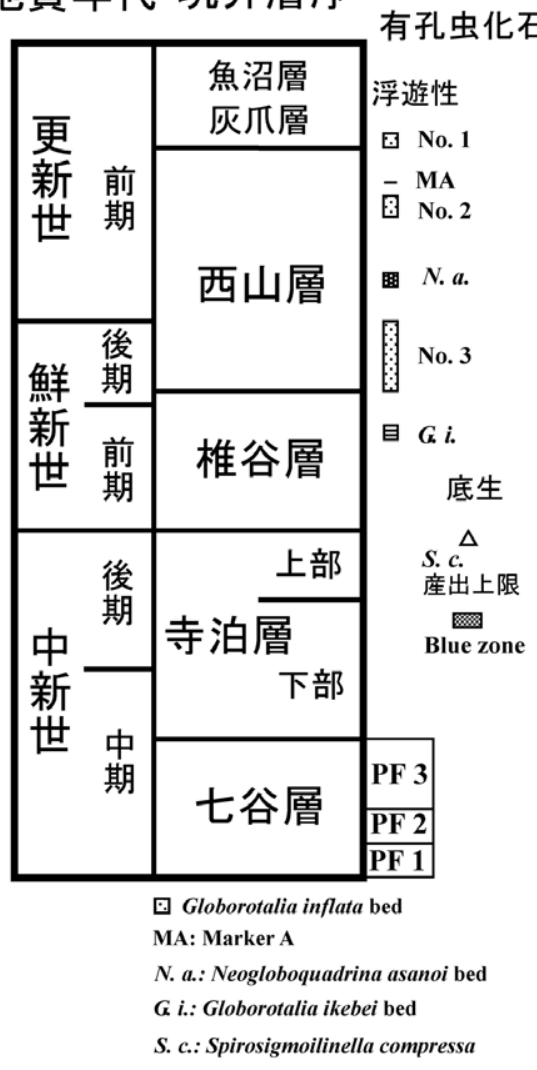

油・ガス田

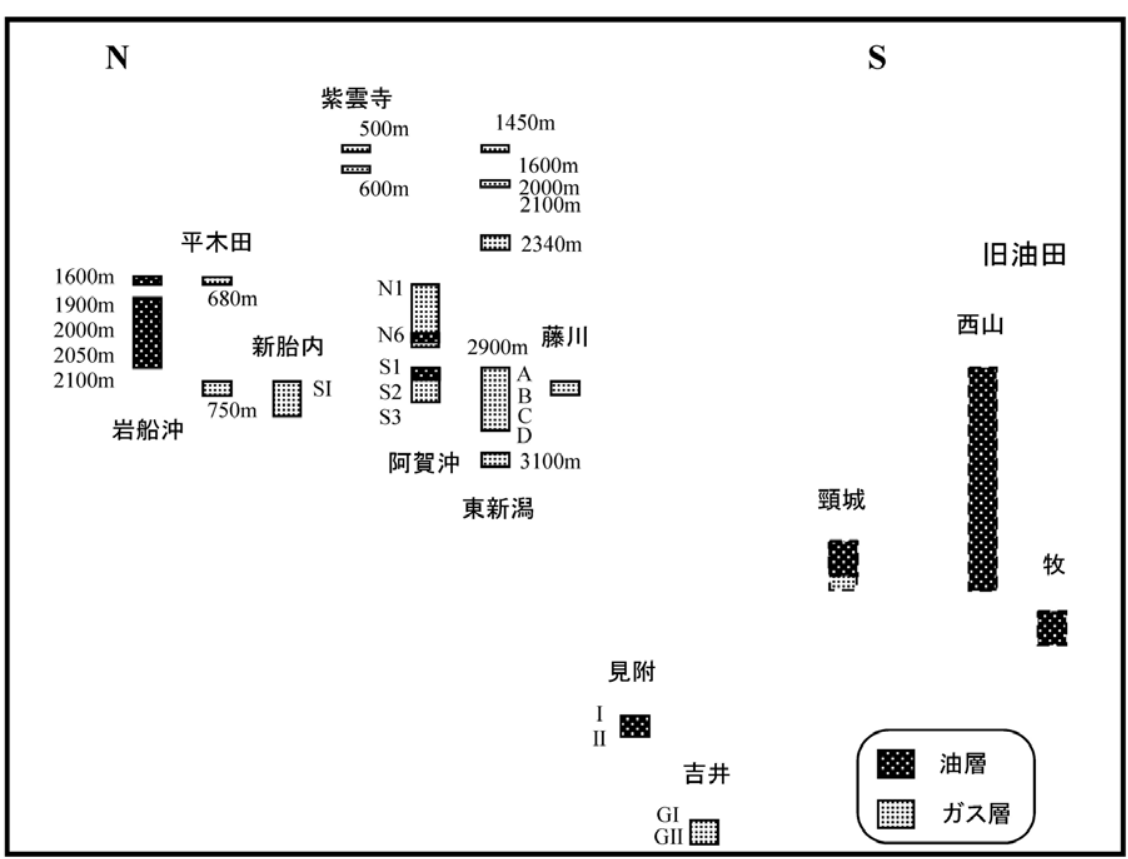

PF 3: Globorotalia peripheroacuta / Globorotalia miozea (s. I.) Zone PF 2: Globorotalia peripheroronda / Globorotalia quinifalcata Zone PF 1: Globigerinoides sicanus / Praeorbulina glomerosa curva Zone

図 2 新潟地域坑井層序と有孔虫化石および油・ガス層 


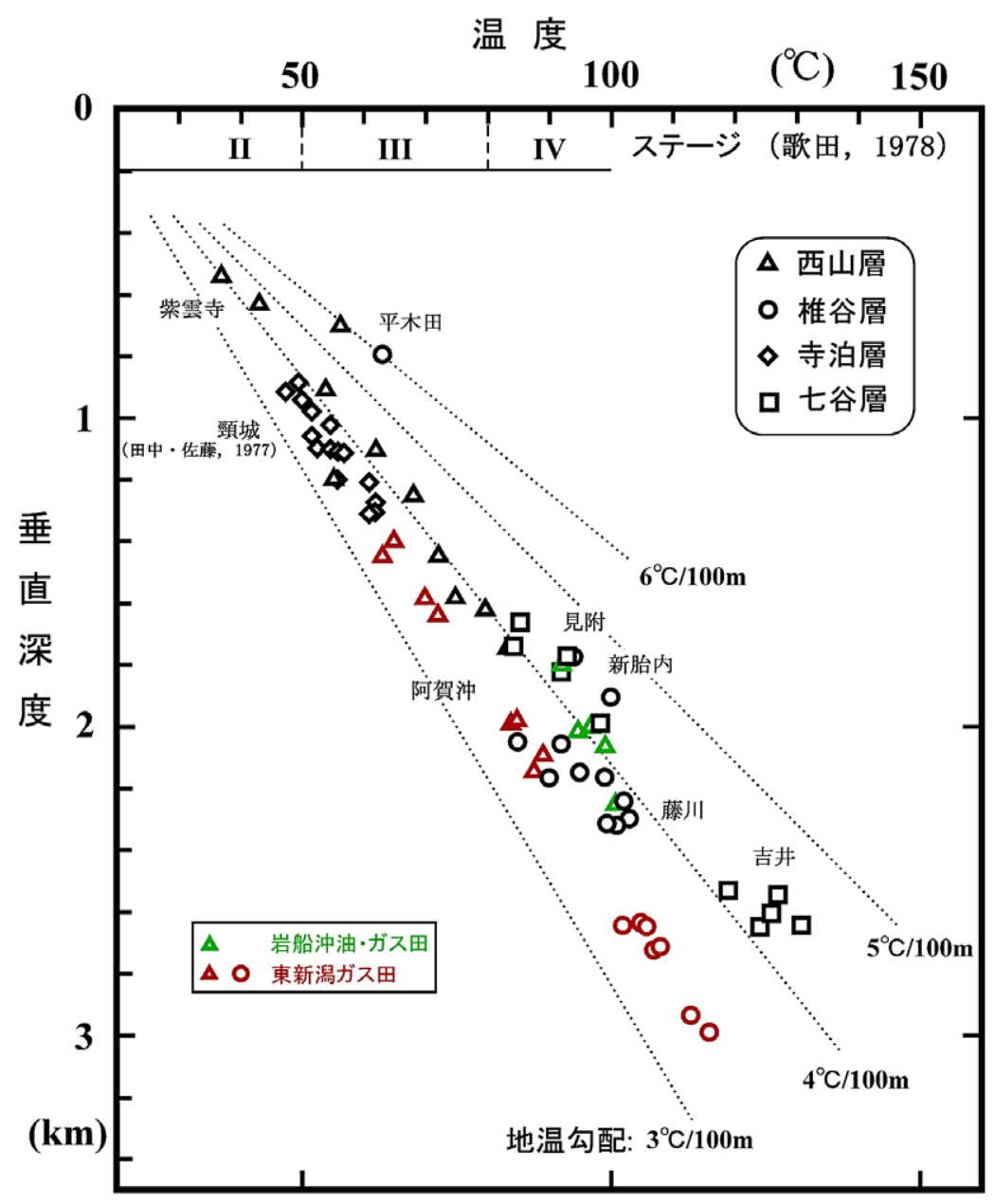

図 3 油・ガス層の深度と温度の関係

接に関係している $\mathrm{NH}_{4}{ }^{+}, \mathrm{HCO}_{3}{ }^{-}, \mathrm{I}^{-}$(須藤, 1967 ; 工藤, 1983）の濃度が著しく増加している。これは油・ガス田の 地層水の特徵である（杉崎ほか, 1963 ; 加藤, 2014）。

西島（1971）は， $\mathrm{NaCl}$ の值は累層ごとにおおよそ一定 の範囲内の值をとる場合が多いと述べている。以下では油・ ガス層の層準を累層ごとに分けて（西山層は上部と下部に 細分可能), 地層水がごのように変化しているかを追跡す る。使用するデー夕は技術研究所で分析したものに加え, 主に寺泊層のデータとして頸城油・ガス田（井上・相場, 1960 ; 相場, 1965 ; 鎮守, 1968), 西山油田・牧油田（本 島ほか, 1955), 西山油田（野口・森崎, 1971）のものを 引用してあるが，できるだけ地表水（天水）の混合がない と推定されるものを使用した。なお，層準が不明な野口・ 森崎（1971）では深度 $700 〜 1,000 \mathrm{~m}$ を椎谷層, 深度 1,000 $\mathrm{m}$ 以深を寺泊層として用いる。

主要イオンである $\mathrm{Na}^{+}$と $\mathrm{Cl}^{-}$をプロットしたものを図 4 に示す。この図の上段には $\mathrm{Na}^{+}$の分析值がない頸城油・ガ ス田, 西山油田・牧油田の $\mathrm{Cl}^{-}$濃度を示す。 $\mathrm{Cl}^{-}$濃度は西 山層の地層水に海水の值 $(19,890 \mathrm{mg} / l)$ よりも高いもの (紫雲寺ガス田と東新潟ガス田) が認められるが, 椎谷層 以下の層準のものはすべて海水の值よりも低い。西山層地
層水の $\mathrm{Cl}^{-}$濃度は海水よりも高いものを除けば, 8,000 $15,500 \mathrm{mg} / l$ の範囲に入る。椎谷層では地層水の $\mathrm{Cl}^{-}$濃度 はかなり変化しており, 約 $5,500 \sim 18,000 \mathrm{mg} / l$ の範囲で ある。一方, 寺泊層や七谷層では地層水の $\mathrm{Cl}^{-}$濃度は比較 的集中しており, それぞれ約 $5,000 \sim 10,000 \mathrm{mg} / l$, 約 8,000 〜 13,500 mg/l である。頸城油・ガス田では下位の層ほ ど $\mathrm{Cl}^{-}$濃度が低くなる傾向があり（例えば, 井上・相場, 1960), 明治ガス田の最下位ガス層である IV 層（寺泊層下 部）では $\mathrm{Cl}^{-}$濃度は $4,000 \mathrm{mg} / l$ 未満である（鎮守, 1968 )。

地層水の $\mathrm{Na}^{+}$濃度が海水の值 $(10,560 \mathrm{mg} / \mathrm{l})$ よりも高 いものは一部の西山層や椎谷層（阿賀沖油・ガス田と藤川 ガス田）に認められるが, 大部分は海水の值よりも低い。 $\mathrm{Na}^{+} / \mathrm{Cl}^{-}$比（重量比, 以下同じ）は海水と同程度かやや大 きく, 特に西山層や椎谷層では海水比の 1.4 倍程度と大き い。これは本邦の油・ガス田の地層水の特徵である（室 住, 1960)。また, 岩船沖油・ガス田や東新潟ガス田では $\mathrm{Cl}^{-}$濃度が減少すると $\mathrm{Na}^{+} / \mathrm{Cl}^{-}$比が大きくなる傾向が認め られる(図 4)。

地層水の $\mathrm{K}^{+}$濃度は一部の西山層で海水の值 $(380 \mathrm{mg} / l)$ よりも高く, 特に紫雲寺ガス田で高いが, 西山層中で急激 に減少し, 大部分は約 $50 \sim 300 \mathrm{mg} / l$ の範囲に入る (図 5)。 
七谷層では吉井ガス田と見附油田との間で $\mathrm{K}^{+}$濃度に違い が認められる。 $\mathrm{K}^{+} / \mathrm{Cl}^{-}$比は西山層および七谷層（吉井ガ ス田）で海水よりも大きいが，椎谷層や寺泊層の地層水は

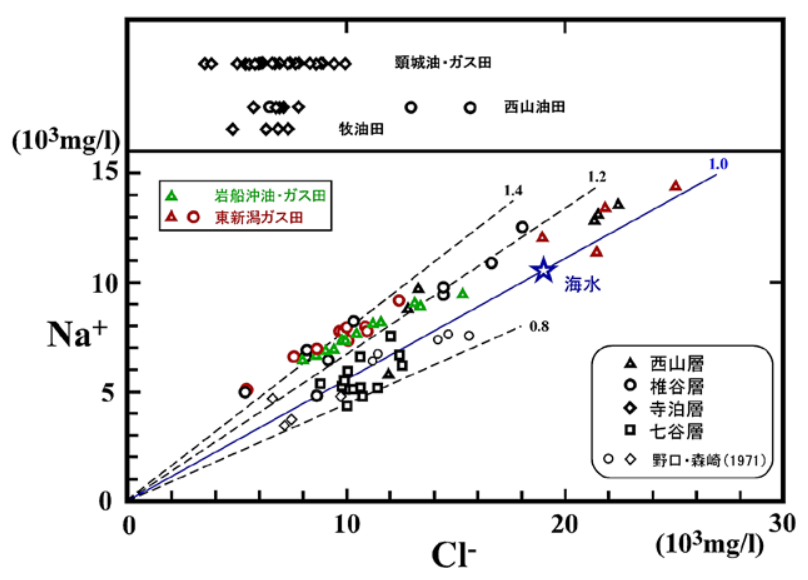

図 4 地層水の $\mathrm{Na}^{+}$濃度と $\mathrm{Cl}^{-}$濃度の関係および旧油 田と頸城油・ガス田における $\mathrm{Cl}^{-}$濃度分布（上）

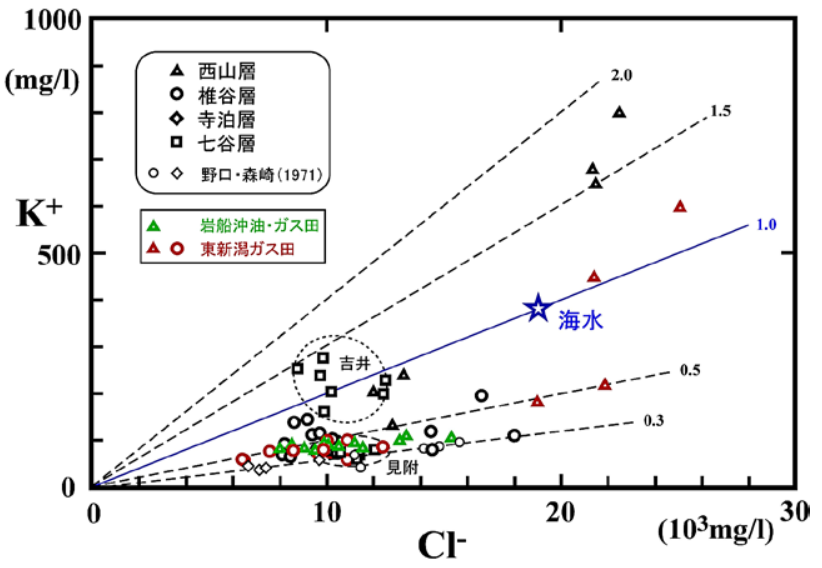

図 5 地層水の $\mathrm{K}^{+}$濃度と $\mathrm{Cl}^{-}$濃度の関係

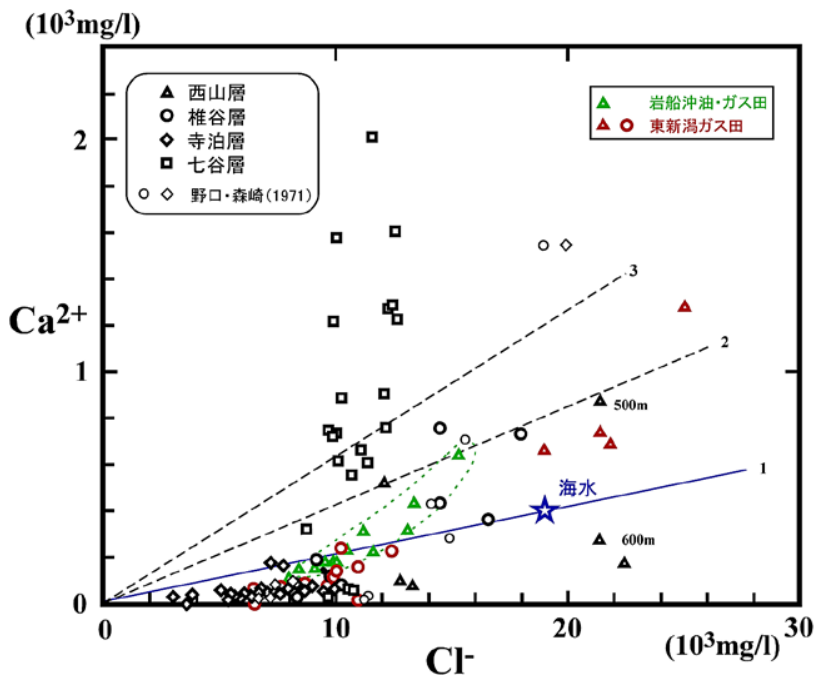

図 6 地層水の $\mathrm{Ca}^{2+}$ 濃度と $\mathrm{Cl}^{-}$濃度の関係
すべて海水よりも小さく, 海水の $0.3 \sim 0.5$ 程度のもが多い。 若い層準の地層水で $\mathrm{K}^{+} / \mathrm{Cl}^{-}$比が海水よりも大きいことは 秋田地域でも認められる（加藤，2014）。

地層水の $\mathrm{Ca}^{2+}$ 濃度は 6 ～約 $2,000 \mathrm{mg} / l$ と大きく変化し ており，火山岩が貯留岩である七谷層で特に高く，一部の 西山層や椎谷層（藤川ガス田）, 西山油田でも海水の值 $(400$

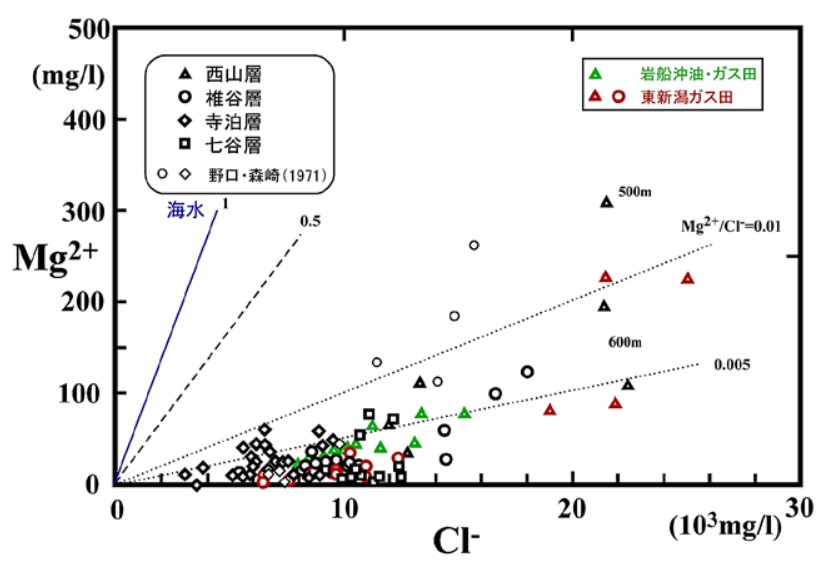

図 7 地層水の $\mathrm{Mg}^{2+}$ 濃度と $\mathrm{Cl}^{-}$濃度の関係

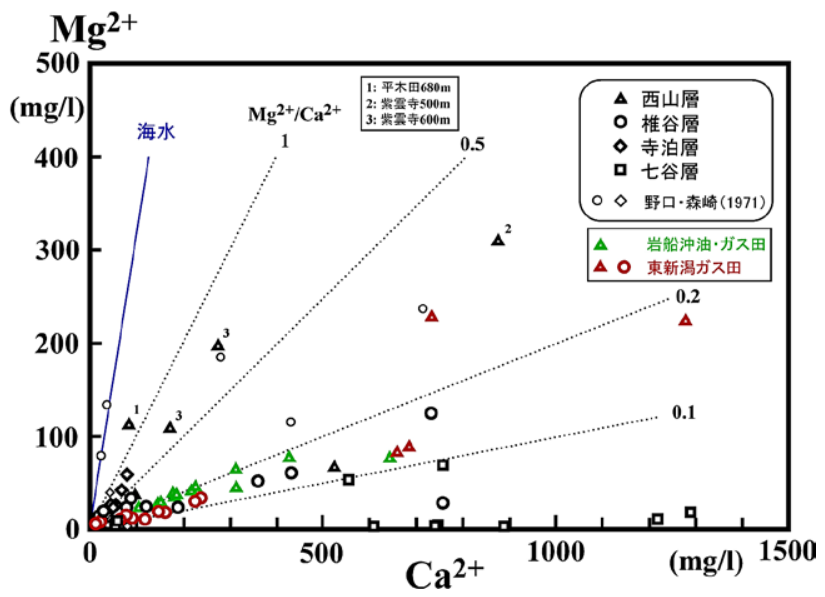

図 8 地層水の $\mathrm{Mg}^{2+}$ 濃度と $\mathrm{Ca}^{2+}$ 濃度の関係

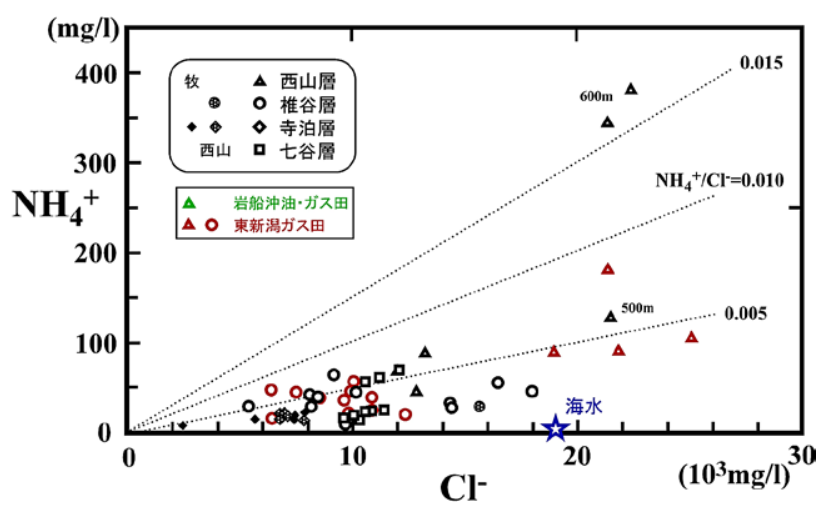

図 9 地層水の $\mathrm{NH}_{4}{ }^{+}$濃度と $\mathrm{Cl}^{-}$濃度の関係 
$\mathrm{mg} / \mathrm{l}$ ) よりも高い（図 6)。 $\mathrm{Ca}^{2+} / \mathrm{Cl}^{-}$比は海水よりも大き いものも小さいものもあるが, $\mathrm{Ca}^{2+}$ 濃度が海水の值よりも 高いものはすべてこの比が海水よりも大きい。岩船沖油・ ガス田や東新潟ガス田の西山層では $\mathrm{Cl}^{-}$濃度が低くなると この比が小さくなっている。また，紫雲寺ガス田では西山 層の $500 \mathrm{~m}$ 層から $600 \mathrm{~m}$ 層へとこの比が急激に小さくなる。

地層水の $\mathrm{Mg}^{2+}$ 濃度はすべて海水の值 $(1,270 \mathrm{mg} / \mathrm{l})$ よ りも低く, 西山層, 椎谷層の順に減少する傾向が認められ, 椎谷層以下の層準ではほとんどが $75 \mathrm{mg} / \mathrm{l}$ 以下である（図 7)。 $\mathrm{Mg}^{2+} / \mathrm{Cl}^{-}$比も地層水はすべて海水より小さく, 西山
層の一部と西山油田の一部を除き 0.01 より小さい。また, $\mathrm{Mg}^{2+} / \mathrm{Ca}^{2+}$ 比は $\mathrm{Ca}^{2+}$ 濃度が $100 \mathrm{mg} / l$ 未満で大きく, 西山 油田の一部では海水と同程度，平木田ガス田の $680 \mathrm{~m}$ 層で $1 よ り 大 き い($ 図 8)。また, この図では省いてあるが頸 城油・ガス田の一部でも $\mathrm{Mg}^{2+} / \mathrm{Ca}^{2+}$ 比は 1 より大きい。 $\mathrm{Ca}^{2+}$ 濃度が $100 \mathrm{mg} / l$ 以上では西山層や西山油田の椎谷層 の一部で $\mathrm{Mg}^{2+} / \mathrm{Ca}^{2+}$ 比が大きいが, 多くは約 0.2 以下であ る。地質年代の古い地層水でこの比が小さくなることが南 関東ガス田などでも知られている（例えば, 福田, 1979)。 地層水の $\mathrm{NH}_{4}{ }^{+}$濃度は海水の值 $(0.05 \mathrm{mg} / l)$ よりも高い

表 1 新潟地域油・ガス田における主な地層水の化学組成および水素・酸素同位体組成

\begin{tabular}{|c|c|c|c|c|c|c|c|c|c|c|c|c|c|c|c|c|c|c|}
\hline \multirow[t]{2}{*}{ No. } & \multirow[t]{2}{*}{$\begin{array}{c}\text { 油・ } \\
\text { ガス田名 }\end{array}$} & \multirow[t]{2}{*}{ 坑井名 } & \multirow[t]{2}{*}{ 累層 } & \multirow[t]{2}{*}{$\begin{array}{c}\text { 油・ } \\
\text { ガス層 }\end{array}$} & \multirow[t]{2}{*}{$\begin{array}{l}\text { TDS } \\
(\mathrm{mg} / \mathrm{l})\end{array}$} & \multirow[t]{2}{*}{$\mathrm{pH}$} & \multicolumn{10}{|c|}{$\begin{array}{c}\text { イオン濃度 } \\
(\mathrm{mg} / \mathrm{l})\end{array}$} & \multicolumn{2}{|c|}{$\begin{array}{c}\text { 同位体組成 } \\
(\% 0)\end{array}$} \\
\hline & & & & & & & $\mathrm{Na}^{+}$ & $\mathrm{K}^{+}$ & $\mathrm{Ca}^{2+}$ & $\mathrm{Mg}^{2+}$ & $\mathrm{NH}_{4}^{+}$ & $\mathrm{Cl}^{-}$ & $\mathrm{SO}_{4}^{2-}$ & $\mathrm{HCO}_{3}^{-}$ & $\mathrm{I}^{-}$ & $\mathrm{Br}^{-}$ & $\delta \mathrm{D}$ & $\delta^{18} 0$ \\
\hline \multirow[t]{6}{*}{1} & 岩船沖 & & & & & & & & & & & & & & & & & \\
\hline & & SIM- B5 & $\mathrm{Ny}$ & $1600 \mathrm{~m}$ & 32,800 & 7.19 & 9,470 & 105 & 645 & 77 & & 15,300 & 5 & 1,100 & 79 & & -10 & -1.4 \\
\hline & & B7 & $\mathrm{Ny}$ & $1900 \mathrm{~m}$ & 25,200 & 7.26 & 8,140 & 84 & 221 & 41 & & 11,600 & $<4$ & 1,900 & 57 & 115 & -12 & -0.2 \\
\hline & & B6 & $\mathrm{Ny}$ & $2000 \mathrm{~m}$ & 26,900 & 7.38 & 9,060 & 101 & 315 & 45 & & 13,100 & $<4$ & 1,700 & 62 & 124 & -12 & -0.9 \\
\hline & & B1 & $\mathrm{Ny}$ & $2050 \mathrm{~m}$ & 20,600 & 7.25 & 6,730 & 90 & 146 & 27 & & 8,460 & 12 & 2,200 & 32 & 85 & -13 & -3.9 \\
\hline & & B8 & $\mathrm{Ny}$ & $2100 \mathrm{~m}$ & 22,400 & 7.46 & 7,390 & 88 & 186 & 36 & & 10,000 & $<20$ & 1,900 & 40 & & -13 & -0.1 \\
\hline \multirow[t]{3}{*}{2} & 平木田 & & & & & & & & & & & & & & & & & \\
\hline & & SK- 11D & $\mathrm{Ny}$ & $680 \mathrm{~m}$ & 30,300 & 7.96 & 9,660 & 246 & 84 & 112 & 89 & 13,300 & 5 & 3,430 & 52 & 99 & -21 & -2.6 \\
\hline & & SK- 7 & Sy & $750 \mathrm{~m}$ & 22,900 & 8.14 & 5,010 & 45 & 21 & 13 & 28 & 5,350 & 12 & 4,510 & 16 & 39 & -10 & 0.6 \\
\hline \multirow[t]{2}{*}{3} & 新胎内 & & & & & & & & & & & & & & & & & \\
\hline & & NS- 9 & Sy & SI & 18,800 & 8.04 & 6,540 & 69 & 35 & 13 & 41 & 8,120 & tr & 2,440 & 34 & 61 & -11 & -1.3 \\
\hline \multirow[t]{3}{*}{4} & 紫雲寺 & & & & & & & & & & & & & & & & & \\
\hline & & SK- 25 & $\mathrm{Ny}$ & $500 \mathrm{~m}$ & 38,657 & 6.95 & 13,034 & 647 & 869 & 310 & 127 & 21,500 & 7 & 600 & 80 & 120 & -3 & -3.3 \\
\hline & & SK- 1 & $\mathrm{Ny}$ & $600 \mathrm{~m}$ & 43,300 & 7.87 & 12,800 & 676 & 276 & 197 & 344 & 21,400 & 12 & 1,880 & 94 & 158 & -11 & -3.0 \\
\hline \multirow[t]{3}{*}{5} & 阿賀沖 & & & & & & & & & & & & & & & & & \\
\hline & & SI- A12 & $\mathrm{Ny}$ & N1 & 22,965 & 7.94 & 8,753 & 135 & 99 & 36 & 43 & 12,841 & 12 & 1,443 & 47 & 77 & -4 & 0.4 \\
\hline & & A6 & Sy & $\mathrm{S} 1$ & 22,910 & 7.81 & 8,259 & 105 & 80 & 23 & 45 & 10,285 & 6 & 2,343 & 40 & 69 & -10 & 0.7 \\
\hline \multirow[t]{7}{*}{6} & 東新潟 & & & & & & & & & & & & & & & & & \\
\hline & & NS- 2D & $\mathrm{Ny}$ & $1450 \mathrm{~m}$ & 39,352 & 7.00 & 11,350 & 447 & 735 & 229 & 180 & 21,462 & 9 & 282 & 77 & 94 & -3 & -4.4 \\
\hline & & NS- 4 & $\mathrm{Ny}$ & $2340 \mathrm{~m}$ & 34,100 & 7.10 & 12,000 & 180 & 662 & 82 & 89 & 19,000 & 35 & 880 & 73 & 137 & -8 & -2.7 \\
\hline & & MS- 37 & Sy & $2900 \mathrm{~mA}$ & 26,100 & 6.99 & 9,170 & 89 & 228 & 30 & 20 & 12,400 & 60 & 2,780 & 57 & 117 & -10 & -0.3 \\
\hline & & NS- 33 & Sy & $2900 \mathrm{mB}$ & 22,802 & 8.23 & 7,954 & 98 & 148 & 20 & 45 & 10,018 & 36 & 2,130 & 39 & 61 & -10 & 1.0 \\
\hline & & NS- 13 & Sy & $2900 \mathrm{mD}$ & 22,100 & 7.46 & 7,690 & 81 & 121 & 11 & 22 & 9,860 & 124 & 2,310 & 29 & 84 & -10 & -0.6 \\
\hline & & NS- 10 & Sy & $3100 \mathrm{~m}$ & 15,500 & 7.97 & 5,150 & 61 & 9 & 3 & 16 & 6,400 & 59 & 2,310 & 13 & 40 & -9 & 0.1 \\
\hline \multirow[t]{2}{*}{7} & 藤川 & & & & & & & & & & & & & & & & & \\
\hline & & SK- 7D & Sy & I & 27,805 & 8.15 & 9,704 & 119 & 434 & 61 & 32 & 14,413 & 677 & 915 & 25 & 64 & -4 & -1.5 \\
\hline \multirow[t]{3}{*}{8} & 見附 & & & & & & & & & & & & & & & & & \\
\hline & & SK- 40 & $\mathrm{Nt}$ & I & 21,600 & 7.44 & 6,590 & 76 & 559 & 54 & 57 & 10,600 & 4 & 1,260 & 14 & 79 & -10 & -0.5 \\
\hline & & SK- 38 & $\mathrm{Nt}$ & II & 20,800 & 6.51 & 6,930 & 83 & 612 & 4 & 62 & 11,300 & 133 & 232 & 7 & 54 & -10 & 1.1 \\
\hline \multirow[t]{5}{*}{9} & 吉井 & & & & & & & & & & & & & & & & & \\
\hline & & SK- 1D & $\mathrm{Nt}$ & GII & 19,000 & 6.59 & 5,240 & 239 & 751 & 7 & 14 & 9,720 & 112 & 153 & 4 & 33 & -11 & 1.5 \\
\hline & & SK- $7 \mathrm{aD}$ & $\mathrm{Nt}$ & GI & 22,800 & 7.07 & 6,720 & 199 & 1,290 & 18 & & 12,400 & 140 & 104 & 5 & 46 & -11 & 0.9 \\
\hline & 安田 & SK- 3D & $\mathrm{Nt}$ & GI & 23,000 & 7.01 & 6,280 & 227 & 1,610 & 10 & & 12,500 & 240 & 64 & 6 & 46 & -12 & 0.6 \\
\hline & 海水* & & & & & 8.20 & 10,560 & 380 & 400 & 1,270 & 0.05 & 18,980 & 2,650 & 130 & 0.05 & 65 & 0 & 0.0 \\
\hline
\end{tabular}

$\mathrm{Ny}$ : 西山層, Sy : 椎谷層, $\mathrm{Nt}$ : 七谷層 
が，大部分は $100 \mathrm{mg} / \mathrm{l}$ 未満である（表 1 )。西山層の一部 では地層水の $\mathrm{NH}_{4}{ }^{+}$濃度が $100 \mathrm{mg} / l$ を超えており, 特に紫 雲寺ガス田の $600 \mathrm{~m}$ 層では $300 \mathrm{mg} / \mathrm{l}$ を超えている (図 9)。 $\mathrm{NH}_{4}{ }^{+} / \mathrm{Cl}^{-}$比は紫雲寺ガス田の $600 \mathrm{~m}$ 層では $1.5 \times 10^{-2}$ を 超えているが，その他は $1.0 \times 10^{-2}$ より小さい。

次に, 陰イオン $\left(\mathrm{SO}_{4}{ }^{2-}, \mathrm{HCO}_{3}{ }^{-}, \mathrm{I}^{-}, \mathrm{Br}^{-}\right)$について述べる。 海水の $\mathrm{SO}_{4}{ }^{2-}$ 濃度は $2,650 \mathrm{mg} / \mathrm{l}$ であるが, 地層水の $\mathrm{SO}_{4}{ }^{2-}$ 濃度は一般に非常に低く数 $10 \mathrm{mg} / l$ 未満である（表 1$) 。$ しかしながら, 藤川ガス田では $\mathrm{SO}_{4}{ }^{2-}$ 濃度は $700 \sim 900$ $\mathrm{mg} / \mathrm{l}$ と高く, また七谷層の $\mathrm{SO}_{4}{ }^{2-}$ 濃度も $100 \mathrm{mg} / \mathrm{l}$ を超え ており，火山ガスの影響と考えられている（工藤, 1983）。

地層水の $\mathrm{HCO}_{3}{ }^{-}$濃度は西山油田の寺泊層や平木田ガス 田椎谷層（750 m 層）では最大で約 $4,500 \mathrm{mg} / \mathrm{l}$ にもなり, 七谷層の一部を除き海水の值 $(130 \mathrm{mg} / \mathrm{l})$ よりも高い。全 体として $\mathrm{Cl}^{-}$濃度が減少すると $\mathrm{HCO}_{3}{ }^{-}$濃度は増加する傾向 が認められる（図 10）。同じ傾向は秋田地域の油・ガス田 地層水にも認められる（加藤, 2014）。詳細にみると, 岩 船沖油・ガス田の西山層では $\mathrm{Cl}^{-}$濃度が減少すると $\mathrm{HCO}_{3}$ 一濃度が増加している。また, 寺泊層では $\mathrm{Cl}^{-}$濃度は余り

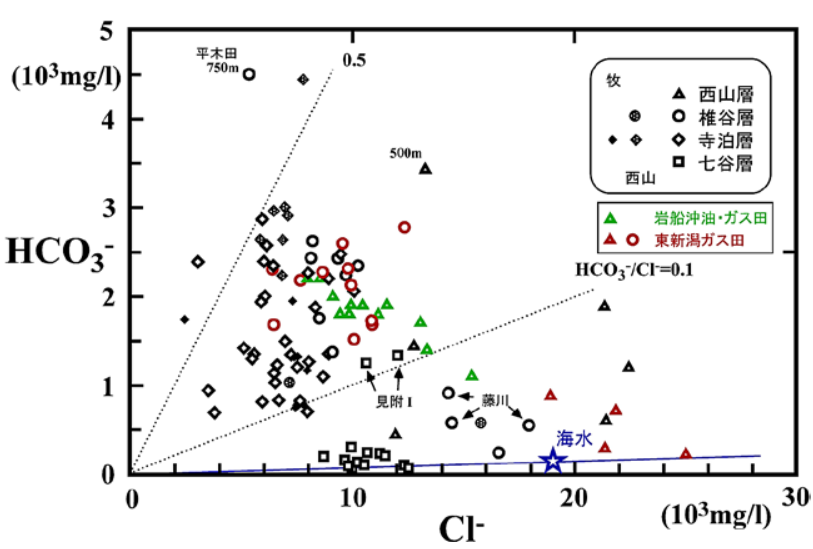

図 10 地層水の $\mathrm{HCO}_{3}{ }^{-}$濃度と $\mathrm{Cl}^{-}$濃度の関係

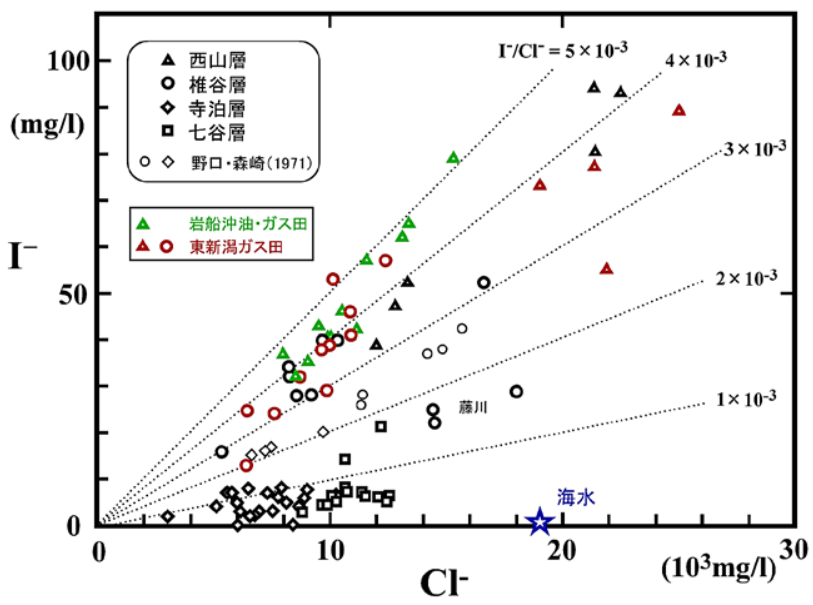

図 11 地層水の $\mathrm{I}^{-}$濃度と $\mathrm{Cl}^{-}$濃度の関係
変化しないが, $\mathrm{HCO}_{3}{ }^{-}$濃度が約 $700 \sim 3,000 \mathrm{mg} / \mathrm{l}$ とかな り変化している。さらに, 同じ油・ガス田の同じ累層でも $\mathrm{HCO}_{3}{ }^{-}$濃度は異なる場合があり, 見附油田の I 層と II 層が その例である（表 1)。 $\mathrm{HCO}_{3}{ }^{-} / \mathrm{Cl}^{-}$比はほどんどが海水よ りも大きく，おおよそ 0.1 を境に大きく 2 つのグループに 分かれ, $\mathrm{HCO}_{3}{ }^{-} / \mathrm{Cl}^{-}$比 $\geqq 0.1$ のグループは主に椎谷層（藤 川ガス田を除く）と寺泊層および西山層の一部の地層水か らなる。

地層水の $\mathrm{I}^{-}$濃度は寺泊層の一部（頸城油・ガス田） を除くすべてが海水 $(0.05 \mathrm{mg} / \mathrm{l})$ よりも高く, 最大が西 山層（紫雲寺ガス田の $600 \mathrm{~m}$ 層）の $94 \mathrm{mg} / l$ であり， 50 $\mathrm{mg} / \mathrm{l}$ を超えるものは西山層および椎谷層の一部の地層水 に限られる（図 11）。一方，寺泊層や七谷層の地層水では, $\mathrm{I}^{-}$濃度は $10 \mathrm{mg} / \mathrm{l}$ 未満のものが多い。 $\mathrm{I}^{-} / \mathrm{Cl}^{-}$比はおおよそ $5 \times 10^{-3}$ 以下であり, $2 \times 10^{-3}$ を境に 2 つのグループに分 かれる。 $\mathrm{I}^{-} / \mathrm{Cl}^{-}$比が小さいグループは藤川ガス田の椎谷層, 西山油田を除く寺泊層, 七谷層の地層水からなる。残りの $\mathrm{I}^{-} / \mathrm{Cl}^{-}$比が大きいグループは主に椎谷層, 西山層の地層水 である。

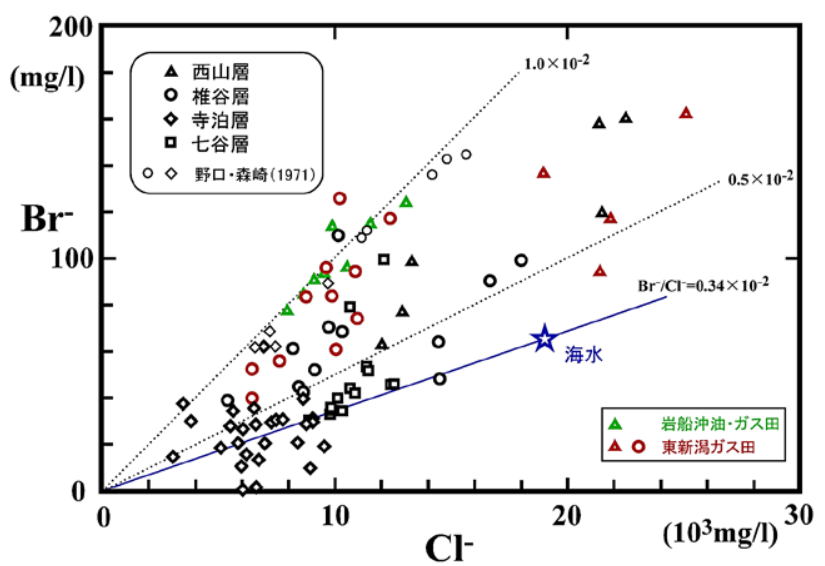

図 12 地層水の $\mathrm{Br}^{-}$濃度と $\mathrm{Cl}^{-}$濃度の関係

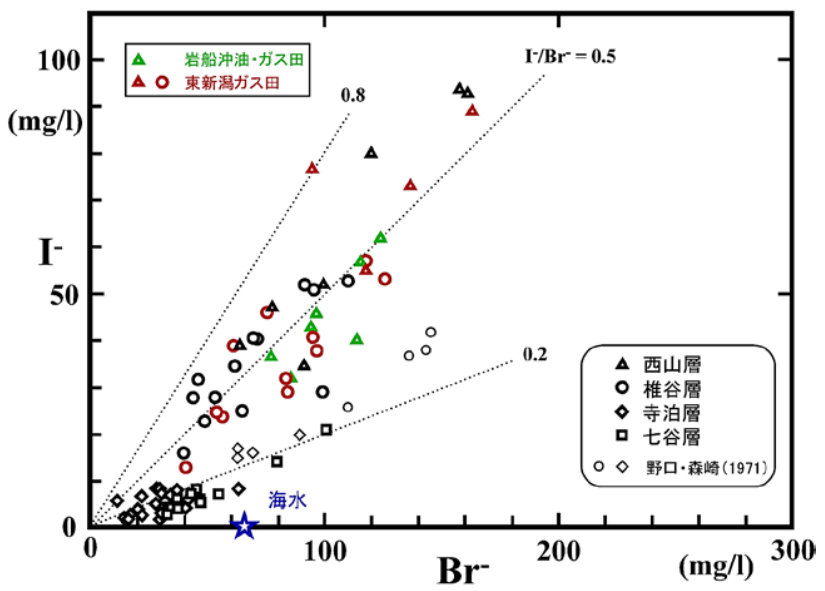

図 13 地層水の $\mathrm{I}^{-}$濃度と $\mathrm{Br}^{-}$濃度の関係 
地層水の $\mathrm{Br}^{-}$濃度は海水 $(65 \mathrm{mg} / l)$ よりも高いものも 低いものもあるが, $\mathrm{Br}^{-} / \mathrm{Cl}^{-}$比は寺泊層の一部を除けば海 水 $\left(0.34 \times 10^{-2}\right)$ と同程度か大きいが，ほとんどが $1.0 \times$ $10^{-2}$ 以下である（図 12）。

地層水の $\mathrm{I}^{-}$濃度と $\mathrm{Br}^{-}$濃度の関係を図 13 に示す。地層 水の $\mathrm{I}^{-} / \mathrm{Br}^{-}$比は海水よりも大きいが，最大でも 0.8 程度 であり，この比が 0.2 未満となるのは寺泊層と七谷層の地 層水のみである。

\section{4. 地層水の水素・酸素同位体組成}

地層水の水素と酸素の同位体組成（ $\left.\delta \mathrm{D}, \quad \delta^{18} \mathrm{O}\right)$ 分析は 主に石油資源開発(株)技術研究所で行い，一部は名古屋大学 中井信之教授（当時）に依頼した。 $\delta \mathrm{D}-\delta{ }^{18} \mathrm{O}$ のプロッ 卜を図 14 に示す。比較のために, この図には海水のほか に天水線（Meteoric Water Line: MWL；Craig, 1961），地表 水のデー夕（Mizota and Kusakabe, 1994），新潟水溶性ガス 田水（中井ほか，1974）などもプロットしてある。地層水 の $\delta \mathrm{D}$ は $-21 \sim-3 \%, \quad \delta{ }^{18} \mathrm{O}$ は $-4.8 \sim+1.6 \%$ の範囲で変 化しており，これは加藤・梶原（1986）が報告した地層水 の範囲（ $\delta \mathrm{D}:-20 \sim-8 \%, \quad \delta^{18} \mathrm{O}:-4.0 \sim+3.5 \%$ ） よ りも少し分散し， $\delta \mathrm{D}$ はやや大きい方へ， $\delta{ }^{18} \mathrm{O}$ はやや小 さい方へシフトしている。 $\delta^{18} \mathrm{O}$ は西山層の地層水で小さ いものが多く，椎谷層，七谷層の地層水で大きくなる傾向 が認められ，加藤・梶原（1986）でもこの傾向を認めてお り，地層温度が高いものほど $\delta^{18} \mathrm{O}$ が大きくなることを指 摘している。一方, 水溶性ガス田水は天水線付近を変化し ており，一部は地層水の範囲内にプロットされている。ガ ス層の場合，地下でガス中に含まれている水蒸気が地表に おいて凝縮する。この凝縮水（condensed water） は $\mathrm{Cl}^{-}$濃 度が低く,地層水に比べ $\delta \mathrm{D}$ と $\delta^{18} \mathrm{O}$ がともに小さい（加藤・
梶原，1986；図 14）。 $\delta \mathrm{D}$ が小さい地層水は凝縮水の影響 を受けている可能性がある。

$\delta^{18} \mathrm{O}$ と $\mathrm{Cl}^{-}$濃度の関係を図 15 に示す。地層水の多くは $\mathrm{Cl}^{-}$濃度が $8,000 \sim 14,000 \mathrm{mg} / l, \quad \delta^{18} \mathrm{O}$ が $-1 \sim+2 \%$ の範 囲に集中しているが，加藤・梶原（1986）よりも少し分散 し， $\delta^{18} \mathrm{O}$ はやや小さい方へシフトしている。また，地層 水には $\mathrm{Cl}^{-}$濃度が減少するにつれ， $\delta^{18} \mathrm{O}$ が大きくなる傾 向が認められ，同じ傾向が秋田地域の油・ガス田地層水に も認められる（加藤，2014）。一方，水溶性ガス田水では $\mathrm{Cl}^{-}$濃度が減少すると $\delta^{18} \mathrm{O}$ が小さくなっており（図 15), $\mathrm{Cl}^{-}$濃度が海水に近いものは地層水と同じ範囲にプロット される。凝縮水は地層水よりも $\mathrm{Cl}^{-}$濃度が低く, 地表水よ りも $\delta^{18} \mathrm{O}$ が大きい。西山層や椎谷層の一部の地層水は凝 縮水の影響を受けているかも知れない。

\section{5. 考察}

須藤 (1967), 加藤・梶原 (1986), 加藤（1990）は東新 潟ガス田を中心として, 新潟地域の地層水の $\mathrm{Cl}^{-}$濃度変化 を図示している。これらを参考にして，本稿のデー夕を加 えて累層毎の地層水の模式的な $\mathrm{Cl}^{-}$濃度変化を図 16 に示す。

$\mathrm{Cl}^{-}$濃度が海水の值を超えるものは紫雲寺ガス田の 500 $\mathrm{m}$ 層や $600 \mathrm{~m}$ 層，および東新潟ガス田の $1450 \mathrm{~m}$ 層〜 2340 $\mathrm{m}$ 層であり，これらのガス層は西山層上部に位置してい る（図 2)。加藤（1968）は東新潟ガス田において $\mathrm{Cl}^{-}$濃 度が最も高いのは $1600 \mathrm{~m}$ 層であり，その上方および下方 に低下すると述べており，これと矛盾しない。一方， $\mathrm{Cl}^{-}$ 濃度が最も低くなるのは寺泊層であり，その值は約 5,000 $\mathrm{mg} / l$ である（ただし, 頸城油・ガス田の明治地区では 4,000 $\mathrm{mg} / l$ 未満まで低下している; 鎮守, 1968)。同じような層 準による $\mathrm{Cl}^{-}$濃度変化は秋田地域の八橋油田で認められる

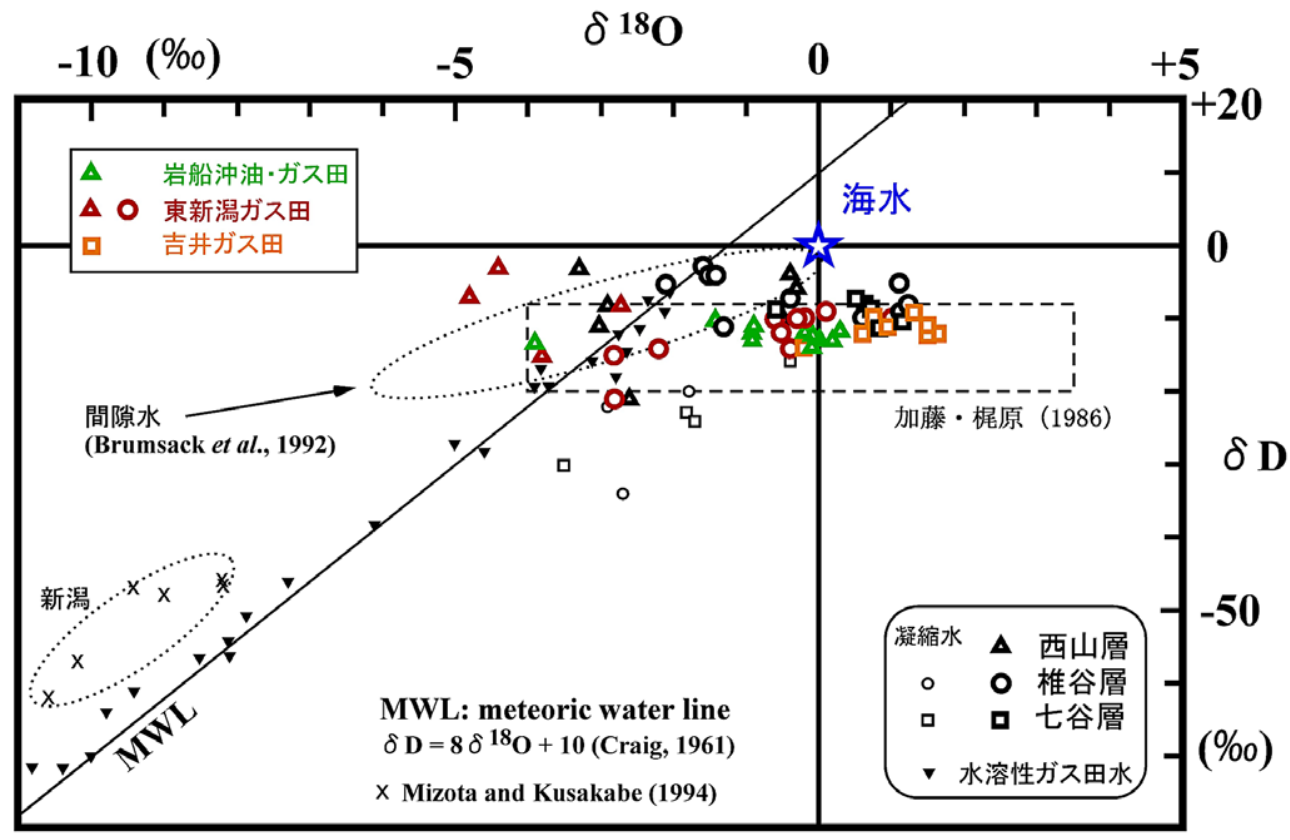

図 14 地層水の $\delta \mathrm{D}$ と $\delta{ }^{18} \mathrm{O}$ の関係 
(本島ほか, 1960)。

西山層上部では $\mathrm{Cl}^{-}$濃度だけでなく $\mathrm{K}^{+} / \mathrm{Cl}^{-}$比も海水よ り大きくなっているが, $\mathrm{Na}^{+} / \mathrm{Cl}^{-}$比は海水と同程度かやや 大きく, 西山層下部〜椎谷層上部で最も大きくなる（図
16)。 $\mathrm{Ca}^{2+} / \mathrm{Cl}^{-}$比は西山層上部で海水の 2 倍程度まで大き くなり, 西山層中で急激に小さくなり, $\mathrm{K}^{+} / \mathrm{Cl}^{-}$比のパター ンに類似している。 $\mathrm{Mg}^{2+} / \mathrm{Cl}^{-}$比は下位の層準ほど小さ

く, 西山層上部で 0.01 程度まで小さくなっている。一方,

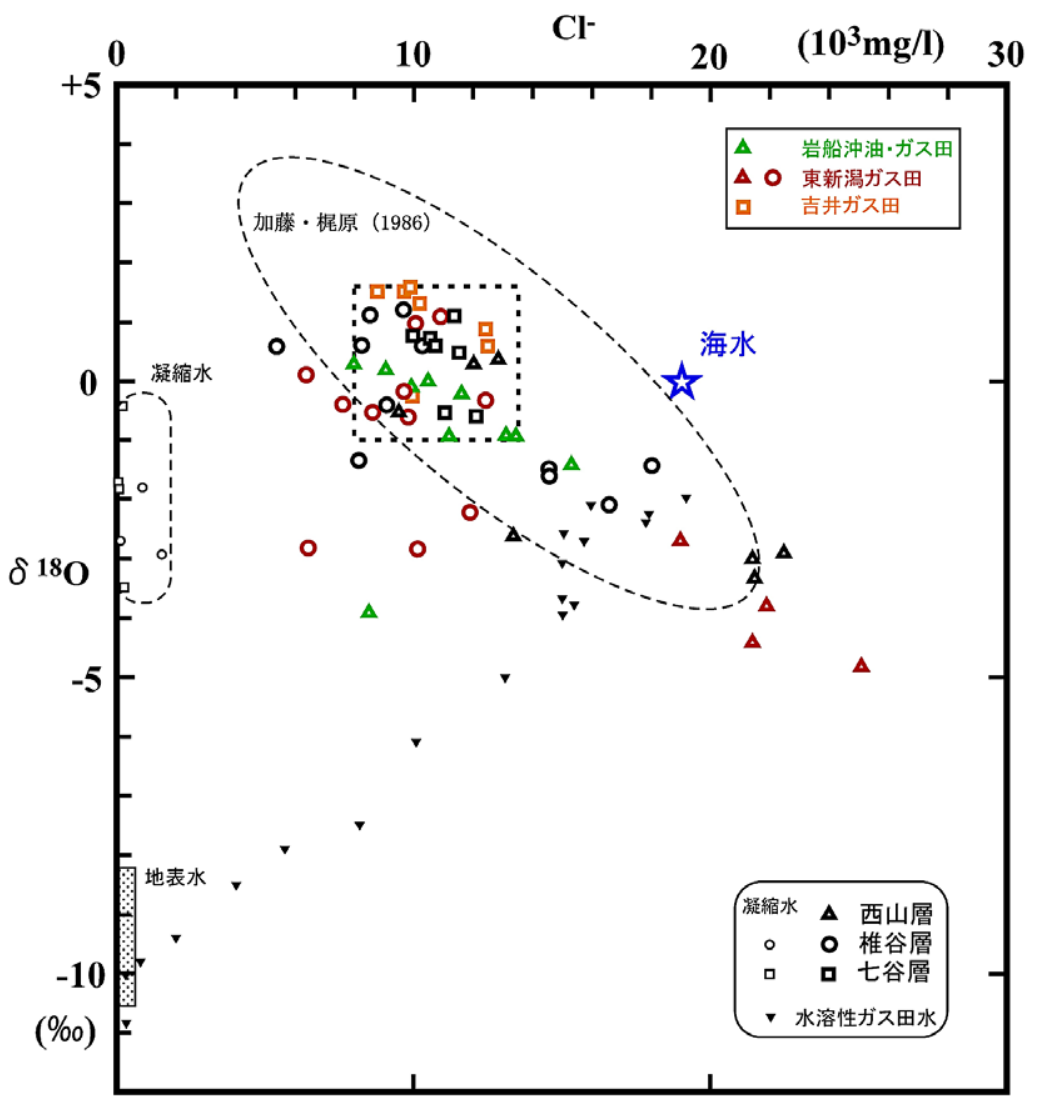

図 15 地層水の $\delta^{18} \mathrm{O}$ と $\mathrm{Cl}^{-}$濃度の関係

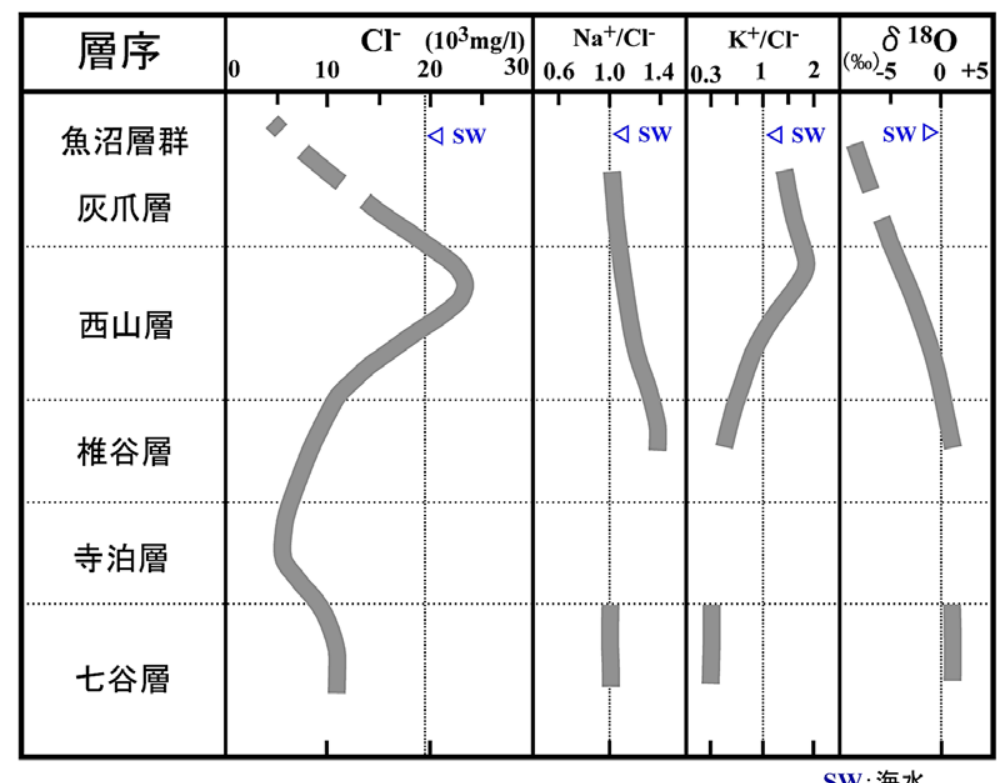

図 16 地層水の $\mathrm{Cl}^{-}$濃度, $\mathrm{Na}^{+} / \mathrm{Cl}^{-}$比, $\mathrm{K}^{+} / \mathrm{Cl}^{-}$比および $\delta^{18} \mathrm{O}$ の層準による模式的な変化 
$\mathrm{HCO}_{3}{ }^{-} / \mathrm{Cl}^{-}$比は西山層上部から椎谷層、寺泊層に向かって 大きくなり (最大で 0.5 程度), 七谷層で海水（約 $0.007 ）$ と同程度まで小さくなる。 $\mathrm{I}^{-} / \mathrm{Cl}^{-}$比と $\mathrm{Br}^{-} / \mathrm{Cl}^{-}$比は西山層 と椎谷層で大きく（それぞれ最大で $5 \times 10^{-3}, 1.0 \times 10^{-2}$ 程度), 寺泊層と七谷層で小さい（それぞれおおよそ $1 \times$ $10^{-3}, 0.5 \times 10^{-2}$ 以下)。

歌田（1978）は海底堆積物における間隙水の化学組成に 認められる海底面から深部に向かう変化パターンを I 〜 III 型の 3 つに整理した上で，陸上では上部に著しい低塩分濃 度域（地表水による希橎）が認められることからこれをIV 型としている。そして，下部では Ia 型の深部延長に類似 する全塩分濃度, $\mathrm{Cl}^{-}$濃度そして $\mathrm{Na}^{+}$濃度の単調な増加や $\mathrm{Mg}^{2+}$ や $\mathrm{K}^{+}$の減少が認められるものを IVa 型としている。 この型では全塩分濃度の最高値は $35,000 \sim 85,000 \mathrm{mg} / l$ 程 度で，その深部ではまた減少し，海水の值より低くなると 述べている。さらに, 我が国の油田地域の地層水の化学 組成変化をこの型とし，地層水の続成変化をステージ I 〜 IV の 4 つに分け，ステージ II/III および III/IV の境界のお およその温度を $50^{\circ} \mathrm{C}$ おび $80^{\circ} \mathrm{C}$ と見積もつている (図 3 )。 地層水の $\mathrm{Cl}^{-}$濃度変化パターンは西山層上部がステージ III （下部）に，西山層下部〜寺泊層がステージ IV に相当して いることを示す。

海水よりも高い $\mathrm{Cl}^{-}$濃度の地層水の形成機構として, 1）温度上昇による蒸発，2）比重による分離（gravitational segregation），3）粘土鉱物による吸着，4）圧密作用，5） 粘土鉱物による半浸透膜効果などが挙げられている(歌田, 1978)。須藤 (1967) は火山ガラスの変質により粘土鉱物 (モ ンモリロナイト）が形成される際に水がかなり吸収される ためと考えている。西山層上部の地層水は $\mathrm{Cl}^{-}$濃度が海水 よりも高く, $\mathrm{K}^{+} / \mathrm{Cl}^{-}$比や $\mathrm{Ca}^{2+} / \mathrm{Cl}^{-}$比も海水より大きいが, $\delta \mathrm{D}$ と $\delta^{18} \mathrm{O}$ は両方とも海水より小さい。日本海で掘削さ れた深海堆積物における間隙水の $\delta \mathrm{D}$ と $\delta^{18} \mathrm{O}$ は深度とと もに小さくなっており（図 14 の点線で囲った領域），その 主な原因は火山ガラスの変質（沸石や粘土鉱物の生成）と 考えられている (Brumsack et al., 1992)。

一方，西山層下部から寺泊層に向かって地層水の $\mathrm{Cl}^{-}$濃 度が減少するステージ IV では, 粘土鉱物の変化（脱水） が原因として挙げられている（歌田，1978）。寺泊層は主 に泥質岩からなり，主要な石油根源岩層準と考えられてい る（例えば，平井ほか，1995）。また，異常高圧層が典型 的に発達する層準でもある（加藤ほか，2009）。 $\mathrm{Cl}^{-}$濃度の 減少と異常高圧層の発達は密接に関係しており (Schmidt, 1973), 新潟地域では地層水の $\mathrm{Cl}^{-}$濃度の減少と貯留層の 初期圧力の増加が相関している（加藤，1988）。異常高圧 が形成される原因として，1）非平衡圧密，2）粘土鉱物 の相転移などに伴う層間水の排出，3）炭化水素の生成や 油のクラッキングなどが有力と考えられている（高畑, 2004)。

安田（1996） は地層水の $\mathrm{Cl}^{-}$濃度の減少と $\delta^{18} \mathrm{O}$ の増加 の主な原因として，粘土鉱物や沸石類の相転移に伴って排 出される “水”（層間水）による希釈が最も可能性の高い
ものと考え，基礎試錐「三島」のカッティングスを用いて 示差熱分析と層間水の $\delta \mathrm{D} と \delta{ }^{18} \mathrm{O}$ 測定を行なった。スメ クタイトからイライトへの相転移で約 $3 \%$ の層間水が排出 され, 抽出した層間水の $\delta \mathrm{D}$ は $-33 \sim-14 \%, \delta{ }^{18} \mathrm{O}$ は +3.8 〜 +9.7\% であり, この可能性を裏付ける結果となっている。

また, 地層水の $\mathrm{Cl}^{-}$濃度の減少は $\mathrm{HCO}_{3}{ }^{-}$濃度の増加と も関係している（図 10）。有機物の熟成に伴って水や $\mathrm{CO}_{2}$ が生成される（例えば, 田口, 1998）ので, $\mathrm{HCO}_{3}{ }^{-}$濃度 の増加はこれに起因していると考えられる。Surdam and MaxGowan（1987）によれば，石油が生成する直前の段階 (地層温度が $80 \sim 120^{\circ} \mathrm{C}$ ) で有機酸が生成されるが，新潟 地域では椎谷層に多量の酢酸が含まれている（武田ほか, 1992)。したがって, 地層水の $\mathrm{Cl}^{-}$濃度の減少は粘土鉱物 の相転移に伴って排出される層間水や有機物の熟成に伴っ て排出される水による希釈が原因と考えられる。

見附油田では泥質岩のコアを用いて間隙水の化学組成が 分析されている（西島，1971）。地層水と比較すると, 間 隙水の $\mathrm{Cl}^{-}$濃度の変化パターンは類似しているが, $\mathrm{Cl}^{-}$濃 度は明らかに低い。一方, $\mathrm{SO}_{4}{ }^{2-}$ 濃度は地層水では通常数 $10 \mathrm{mg} / l$ 未満であるが, 間隙水では海水の值よりも高いも のが多く, 特に寺泊層で高く, $\mathrm{Cl}^{-}$濃度 $<\mathrm{SO}_{4}{ }^{2-}$ 濃度となつ ている。このような地層水（砂岩）と泥質岩の間隙水との 間における塩分濃度や化学組成の違いは米国 Gulf Coast 地 域でも報告されている（Schmidt, 1973）。

\section{6. まとめ}

新潟地域の油・ガス田から採取した地層水の化学組成と 水素・酸素の同位体組成を層準毎に整理し，それらの特徵 と層準（あるいは深度）による変化を明らかにした。地層 水は主に $\mathrm{Na}^{+}$と $\mathrm{Cl}^{-}$からなり, 海水と比較すると, $\mathrm{SO}_{4}{ }^{2-}$ や $\mathrm{Mg}^{2+}$ の濃度が著しく減少し, 有機物に由来する $\mathrm{NH}_{4}{ }^{+}$, $\mathrm{HCO}_{3}{ }^{-}, \mathrm{I}^{-}$の濃度が増加している。 $\delta \mathrm{D}$ は $-15 \sim-3 \%$ の 比較的狭い範囲に集中し, $\delta{ }^{18} \mathrm{O}$ は $-4.8 \sim+1.6 \%$ と大き く変化しており，下位の層準ほど大きくなる傾向がある。

地層水の $\mathrm{Cl}^{-}$濃度は累層ごとにある程度の範囲に入って おり, 西山層上部で最大となり, 海水の值よりも高くなる が, $\delta \mathrm{D}$ と $\delta^{18} \mathrm{O}$ は両方とも海水より小さくなる。これは 火山ガラスの変質により自生鉱物（粘土鉱物や沸石）が生 成されるためと考えられる。一方，下位の西山層下部，椎 谷層そして寺泊層に向かって地層水の $\mathrm{Cl}^{-}$濃度は減少して いる。この $\mathrm{Cl}^{-}$濃度の減少は粘土鉱物の相転移に伴う層間 水や有機物の熟成に伴う水に起因している。

また, 地層水中の $\mathrm{Ca}^{2+}$ 濃度は貯留岩の岩質（特に砂岩 か火山岩か) に強く影響を受けている。

地層水と泥質岩の間隙水の化学組成はかなり異なってい るので, 貯留岩と非貯留岩である泥質岩の両方での続成作 用による変質過程を研究することが必要と考えられる。

\section{謝 辞}

資料の公表を許可された石油資源開発(侏)に深謝します。 同社技術研究所（現 技術本部技術研究所）で水の分析を 
担当された元社員安田善雄, 鈴木 優, ならびに故梶原義 照の各氏に厚くお礼申しあげます。

\section{引用 文 献}

相場惊一，1965：頸城ガス田. 石油学会誌，8(7)，492500.

Brumsack, H.-J., Zuleger, E., Gohn, E. and Murray, R. W., 1992 : Stable and radiogenic isotopes in pore waters from Leg 127, Japan Sea. Proc. ODP, Sci. Reports, 127/128, Pt. 1, 635-650.

Craig, H., 1961 : Isotopic variation in meteoric waters. Science, 133, 1702-1703.

鎮守次郎， 1968 : 明治ガス田の開発. 石油学会誌，11(5), 372-376.

福田 理, 1979 ：共水性ガスとその鉱床（その2). 地質 ニュース, no.296, 6-18.

平井明夫・岡田静子 - 若松屋伸一・八戸和巳, 1995 : 有機 地球化学的にみた新潟地域における原油とその根源岩の 関係. 石技誌，60(1)，87-97.

井上重一・相場惊一, 1960: 頸城ガス田. 石油学会誌, 3(3), 219-223.

加藤正和, 1968: 東新潟ガス田の開発. 石油学会誌, 11 (9), 703-709.

加藤 進, 1988:グリーンタフ鉱床の特徵－新潟地域グリー ンタフ炭化水素鉱床の石油地質学的研究 その 3 -. 石 技誌，53(2)，131-143.

加藤 進, 1990 ：石油鉱床と水 (その 2). 石油の開発と 備蓄, '90-8, 36-47.

加藤 進, 2014 : 秋田地域の油・ガス田地層水の地球化学. 地下水学会誌, 56 (4), 299-307.

加藤 進・梶原義照, 1986 ：新潟地域油・ガス田付随水 の水素・および酸素の同位体組成. 石技誌，51(2), 113-122.

加藤 進 - 早稲田 周 - 西田英毅 - 岩野裕継, 2009：新潟 県東頸城地域における泥火山および周辺の原油・ガスの 地球化学. 地学雑誌, 118(3), 455-471.

風早康平・高橋正明- 安原正也 - 西尾嘉朗 - 稲村明彦・森 川徳敏・佐藤 努・高橋 浩 $\cdot$ 北岡 豪 $\cdot$ 大沢信二 $\cdot$ 尾 山洋一・大和田道子 塚本 斉 - 堀口桂香 - 戸崎裕貴 切田 司, 2014 : 西南日本におけるスラブ起源深部流体 の分布と特徵. 日本水文科学会誌，44(1)，3-16.

工藤修治, 1983：1.2 地層流体. 石油鉱業便覧，23-26.

工藤 崇 - 内野隆之 - 小松原 玩 - 高橋 浩 - 柳沢幸夫, 2011 : 加茂地域の地質. 地域地質研究報告 (5 万分の 1 地質図幅)。産総研地質調查総合センター, 162p.

Mizota, C. and Kusakabe, M., 1994: Spatial distribution of $\delta \mathrm{D}-\delta^{18} \mathrm{O}$ values of surface and shallow groundwater from Japan, with southern Korea and east China. Geochem. Jour., 28, 387-410.
本島公司・石和田靖章・品田芳二郎・牧野登喜男・安国 昇・伊田一善・三梨 昂・影山邦夫, 1955 : 新潟油田の 地化学的予察報告. 地質調查所月報, 6, 123-128.

本島公司・牧 真一・牧野登喜男・柴田 賢, 1960 : 八橋 油田媙水の地球化学. 地質調查所報告, 第 186 号, 81p.

室住正世, 1960 : 新潟ガス田のガス付随水の化学的性質の 特殊性. 石技誌, 25 (3), 124-128.

中井信之・吉田 裕・安藤直行, 1974 : 石油, 天然ガス鉱 床の同位体地球化学. 地球化学, 8, 87-98.

西島 進, 1971 : 新潟県の天然ガス鉱床の研究 [1] - 天 然ガス・地層水の性状一。岩石鉱物鉱床学会誌, 65 , 162-179.

野口喜三雄・森崎重喜, 1971 : 油田およびガス田かん水の リチウムおよびヒ素含量とその地球化学的意義. 日本化 学雑誌，92，145-149.

大沢信二 ・ 網田和宏 - 山田 誠 - 三島壮智 - 風早康平, 2010 : 宮崎平野の大深度温泉井から流出する温泉水の 地化学特性と成因一温泉起源流体としての続成脱水流 体一。温泉科学, 59, 295-319.

Schmidt, G. W., 1973: Interstitial water composition and geochemistry of deep Gulf Coast shales and sandstones. AAPG Bull., 57, 321-337.

須藤能光, 1967 ：日本における油田・ガス田塩水の地球化 学的研究. 石技誌, 32(5), 286-296.

杉崎隆一・吉本泰介・加藤喜久雄・杉浦 孜, 1963 : 南 関東ガス田の地球化学的考察 - とくにガス成分と鉱床 の存在状態との関連について - . 地質学雑誌, 69 (1), $67-81$.

Surdam, R. C. and MacGowan, D. B., 1987: Oilfield waters and sandstone diagenesis. Applied Geochemistry, 2, 613-619.

田口一雄, 1998 : 石油の成因一起源・移動・集積. 共立出 版, $140 \mathrm{p}$.

高橋純一，1932a: 油田鹹水の生成説. 岩石鉱物鉱床学， 7, $72-79$.

高橋純一, 1932b: 油田劌水の生成説（2)。岩石鉱物鉱床学, 7, 131-138.

高畑伸一，2004：地下の圧力構造の把握と石油地質学的解 釈. 石技誌, 69 (2), 167-180.

田中 隆・佐藤勝義, 1977 ：東北日本の油田地域における 地下温度の推定. 石技誌, 42(4), 229-237.

武田信従・星 一良・鈴木 優・安田善雄, 1992：油 田水に含まれる有機酸について. Researches Organic Geochemistry, 8, 47-49.

歌田 実, 1978 : 続成作用における地層水の組成変化. 地 質学論集, 第 15 号, 151-164.

安田善雄, 1996 : 新潟地域油田水の深度に伴う塩化イオン 濃度減少の原因について. 日本地球化学会年会講演要旨 集, 160 . 